\title{
HOLE SELECTION BY NESTING SWIFTS IN MEDIEVAL CITY-WALLS OF CENTRAL SPAIN
}

\author{
SELECCIÓN DE LAS CAVIDADES DE NIDIFICACIÓN \\ POR EL VENCEJO COMÚN EN MURALLAS MEDIEVALES \\ DEL CENTRO DE ESPAÑA
}

\author{
Luis Corrales $^{1}{ }^{*}$, Luis Miguel Bautista ${ }^{2}$, Tomás SANTAMaría ${ }^{1}$ \\ and Pedro MAS ${ }^{1}$
}

SUMMARY.-Disturbance and predation risks from terrestrial animals decline the higher up the nest sites selected by birds that nest in wall cavities are located. Terrestrial predators can also negate the protective quality of higher nesting sites by approaching from above in walls. It is unknown how terrestrial predation risks from below and above walls determine nest site selection in cavity-nesting species. In relation to this situation, we describe nest-site selection in common swifts Apus apus in the medieval city walls of Ávila, Spain. We recorded the entry size, hole depth and the horizontal and vertical positions of cavities. Most cavities were empty despite their size being suitable for nesting. Swifts nested in cavities at least $12 \mathrm{~cm}$ deep and with an entry between $3.5 \mathrm{~cm}$ and $13 \mathrm{~cm}$ wide. Nests were $3.5 \mathrm{~m}$ above the ground and $1.7 \mathrm{~m}$ below the top of the wall, although there were suitable cavities at the lower and higher extremes, respectively. Higher predation risks and disturbances could explain why suitable cavities were empty at lower and higher heights. The distances to the ground and to the top of the wall, as well as the distance to the nearest corner, accounted for about one-tenth of the probability that a cavity was used for nesting. Our data do not indicate a possible reason for nesting near corners, but weather is an obvious candidate.

Key words: Apus apus, castle, cavity-nesting, common swift, nest selection.

RESUMEN.-Las molestias y el riesgo de depredación por animales terrestres determinan que las aves que emplean paredes para anidar seleccionen cavidades a mayor altura. También podrían seleccionar el lugar del nido a menor altura si los depredadores terrestres se encuentran presentes encima de la pared, pero se desconoce cual es la selección de cavidades para anidar cuando hay riesgo de depredación terrestre en ambos lados de la pared. Para dilucidarlo, estudiamos la selección de cavidades en el vencejo común Apus apus en las murallas medievales de Ávila, España. Registramos el tamaño de la entrada, la profundidad de orificio y las posiciones horizontal y vertical de las cavidades. La mayor parte de las cavidades se encontraron vacías, incluso cuando su tamaño era apropiado para anidar. Los vencejos anidaron en cavidades con una profundidad de al menos $12 \mathrm{~cm}$ y orificios de entrada no más pequeños de $3,5 \mathrm{~cm}$ ni mayores de $13 \mathrm{~cm}$. Las oquedades con nidos no se encontraron a menos de

1 Universidad Católica de Ávila, C/ Canteros s/n, 05005 Ávila, Spain.

2 National Museum of Natural History, CSIC. José Gutiérrez Abascal 2, 28006 Madrid, Spain.

* Corresponding author: recogemensajes@yahoo.es 
3,5 m del suelo ni a menos de 1,7 m a la cima de la pared, aunque hubiera cavidades convenientes tanto a menor como a mayor altura. El mayor riesgo de depredación y las molestias tanto cerca del suelo como de las almenas podrían explicar que hubiese cavidades adecuadas para nidificar que sin embargo estaban vacías en ambos extremos de la muralla. Las distancias verticales al suelo y al borde superior de la muralla, junto con la distancia horizontal al rincón más cercano determinaron alrededor de una décima parte de la probabilidad de anidar en una cavidad de dimensiones adecuadas. Los datos registrados no explican las causas de la preferencia para anidar cerca de los rincones, aunque la meteorología sea un candidato obvio.

Palabras clave: Apus apus, cavidad para anidar, muralla, vencejo común, nido.

\section{INTRODUCTION}

Cavity-nesting birds that cannot excavate their own holes depend on the availability of cavities. Consequently, the location and density of breeders should conform to the distribution of suitable holes (Newton, 1998). However, this distribution pattern is not realised in all species: some cavity-nesting bird species prefer buildings with many cavities in the roof and walls (Franco et al., 2005), but a shortage of nest-sites may not have a detrimental effect on the population dynamics in other species (Forero et al., 1996). Where cavities abound, some birds prefer higher nests to avoid terrestrial predators (Fisher and Wiebe, 2006) but other species avoid the upper cavities when nesting on cliffs, for the same reason (Penloup et al., 1997). Therefore, it may be that some cavitynesting bird species select holes in the middle height range to avoid terrestrial predators and disturbances from both above and below. For instance, small tree-nesting bird species often avoid extreme positions at the bottom and top of the tree, and do not select the less dense, external positions within the tree, in order to reduce predation risk (e.g., Alonso et al., 1991). However, as far as we know, previous studies have not reported the same effects in bird species that nest in buildings. Not surprisingly, most terrestrial predators cannot reach nests from above because they do not have access to building roofs. However, old medieval city walls are an exception because disturbance caused by people walking near and above the walls, and nocturnal predation by terrestrial vertebrates such as rodents, can occur from both above and below the nests and are thus plausible determinants of nest-site selection.

Birds that nest in wall cavities, such as some sparrows, swifts and kestrels, may tolerate conspecifics nesting nearby where there are several cavities in the same wall. Common swifts Apus apus nesting in medieval city walls are good candidates with which to study the effects of disturbance and predation risk on the nest-site selection of a cavity-nesting species. Common swifts nest in a wider variety of sites than any other species of Apus (Lack, 1956a). Swifts usually nest in buildings but they can also be found nesting in holes in trees, cliffs and crevices, and even in nestboxes (Beaud, 2010; Froehlich, 2006; Kharkova and Boehme, 2005; Cortes, 2005; Guenther et al., 2009; Beschow, 2003; Cameliti and Boano, 2002; Roger and Fossé, 2001; García and Álvarez, 1996; Holmgren, 1993; Huber, 1990; Gámez, 1989; Ferrero et al., 1983; Vielliard, 1978; Herrera and Ramírez, 1975; Lack, 1956a). It would be expected that there exist plausible reasons for choosing buildings, and at least three such reasons have been identified (Lack, 1956b; Bernis, 1988a): (a) they offer an abundance of available cavities of suitable size; (b) most have a minimum height facili- 
tating take-off; and (c) the minimum open space in front of the nesting hole is sufficient for flight. These three requirements may vary between breeding colonies and therefore their quantification in more than one colony may be informative. This study aims to shed light on the first, taking into account other factors that can determine the preferred nesting height in walls, such as human disturbance and the risk of predation by terrestrial predators from both above and below.

Swifts usually enter their nesting holes with direct flight, and take-off is characterised by an initial free-fall. Therefore, nesting holes should be easily accessible from open space and located at a minimum height. Previous studies of swifts breeding in old buildings have described the height constraint (Pellantová, 1975; Bernis, 1988a): in Spain the nests are 3-5 $\mathrm{m}$ up in small towns (Bernis, 1988b), at 12-16 $\mathrm{m}$ in houses in the Czech Republic (Pellantová, 1975) and above $6 \mathrm{~m}$ in Oxford (some near Oxford were only at $3 \mathrm{~m}$; Lack, 1956b). Given the variability in the minimum heights, it may be that takeoff does not require a height greater than $3 \mathrm{~m}$, although higher nests may serve to conserve energy at the beginning of flight. The availability of cavity heights is limited by the maximum height of the building and the vertical distribution of the cavities. Therefore, it is unclear whether the swifts select holes at the maximum height, or simply avoid holes below $3 \mathrm{~m}$. The effect of the distance to the nearest obstacle, and its interaction with the minimum height of the nests, was not analysed in this study because the sectors of the medieval city walls included were free of nearby obstacles, and therefore flight was not restricted by the distance to the nearest obstacle in front of the nests.

Higher holes may be unsuitable for nesting because of a potentially higher risk of predation from terrestrial predators approaching from above the wall. It is unsurprising that the effect of predation risk from above has not been explored in swifts, because most buildings do not allow roof access to terrestrial predators. The medieval walls, with easy access to the tops of the walls from the inside face, may allow cavity access to rodents from above. Recording rodent presence would indicate whether they can access the wall from both extremes. The presence of mice, as a surrogate measure of the risk of predation, would explain the avoidance by swifts of nest-site locations near the tops and bottoms of walls.

People on the walkway located behind the crenelations of the medieval wall may also disturb the swifts. The walkways are a popular tourist attraction in the city of Ávila: c. 19,000 people walk along them every month (Troitiño et al., 2012) during the swift breeding season. Human disturbance and predation risk are not mutually exclusive and both were considered possible explanations for avoidance by swifts of the cavities located on the upper end of the wall.

Our aim was to compare the size and position of the cavities with and without swift nests, describing the distribution of the cavities in the towers and walls of a fortified medieval city. We also recorded the presence/absence of mouse droppings in cavities suitable for nesting, testing the potential effect of mice on the use of cavities by swifts. Although the risk of predation and the nest height are probably associated, the former is also related to the maximum size of the hole, as described in other species of passerines (e.g., Cordero, 1986; Van Balen et al., 1982). Therefore, we also measured the size of the cavities.

\section{STUDY AREA AND METHODS}

The study was conducted in the fortified city of Ávila, central Spain. The city is surrounded by $2,516 \mathrm{~m}$ of walls and 87 
towers. The walls are about $3 \mathrm{~m}$ thick, $11 \mathrm{~m}$ high and $20 \mathrm{~m}$ wide; towers are about 6-7 m thick, $15 \mathrm{~m}$ high and $27 \mathrm{~m}$ wide. The external side of the walls and towers offer small cavities, some used by cavity nesting bird species such as common swifts. In Ávila the population size of swifts is approximately 12,400 birds (L. Corrales, unpublished). Swift density in the town is about 1,700

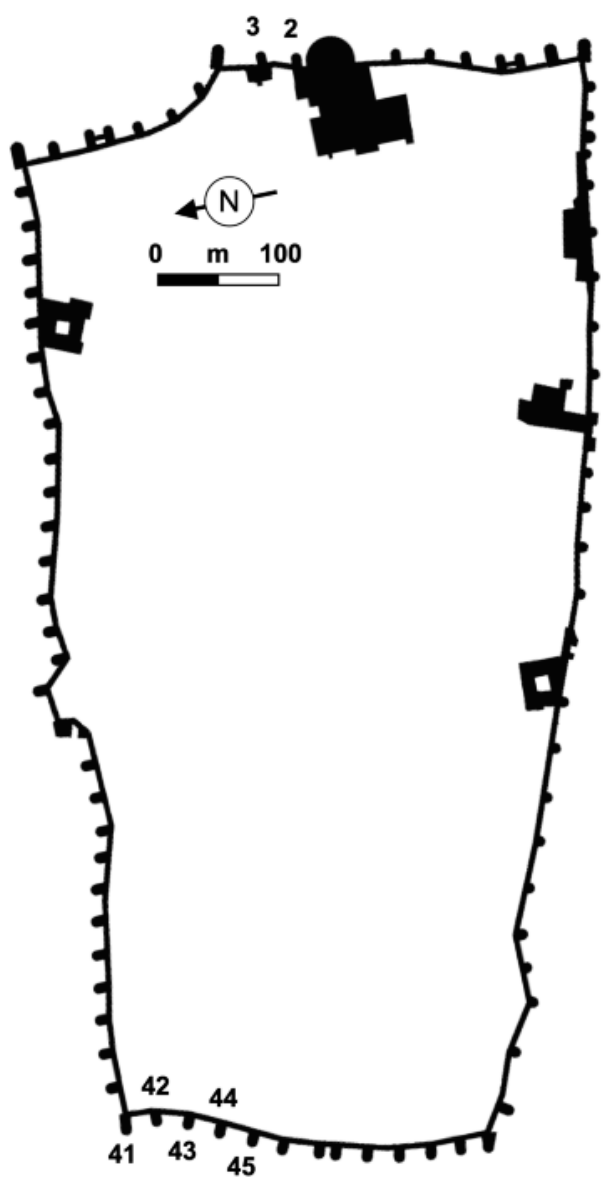

FIG. 1.-Map of the city walls of Ávila (Central Spain) with the two sampling sites highlighted on the east (towers 2-3) and the west (towers 41-45). [Plano de las murallas de Ávila (centro de Espa$\tilde{n} a)$, con dos lugares de muestreo destacados en el este (torres 2-3) y el oeste (torres 41-45).] birds $/ \mathrm{km}^{-2}$ (L. Corrales, unpublished), larger than in other towns of similar size (Bernis, 1988a). In this study we selected two sectors of the medieval walls: between and including towers 2 and 3 (East) and towers 41 to 45 (West, fig. 1). The total length of these towers was $119 \mathrm{~m}$ and the total length of the intermediate walls was $81 \mathrm{~m}$. Overall we looked for cavities in $923 \mathrm{~m}^{2}$ of walls and $2,401 \mathrm{~m}^{2}$ of towers. Cavities were sampled between May and June 2011, when the walls and towers were being restored. An observer used scaffolding erected from the bottom to the top of the walls and towers to inspect the cavities. Each hole was visited only once, because the scaffolding was moved between sites and never returned to a previous location.

We recorded the vertical distance to the ground of each cavity, the horizontal distance to the nearest corner, and the height and length of walls and towers (fig. 2). We measured the maximum and minimum length of the entry to the hole ( $\max$ and $\min , \mathrm{cm}$ ), and calculated the product of $\max \times \min$ $\left(\mathrm{cm}^{2}\right)$ as an index for the size of the entry. Hole depth (D, cm) was also measured.

Cavities were classified as occupied and empty. Empty cavities of similar dimensions to occupied ones were labelled as 'suitable', and empty cavities of different dimensions to occupied ones were labelled as 'unsuitable'.

We recorded the presence/absence of excrement in cavities suitable for nesting. Mouse abundance was not sampled because the erection of scaffoldings and maintenance work would have affected mouse presence. We did not record the frequency of people walking above or below the medieval walls, because this was recorded by the city tourism department. The medieval city walls were open to public access every day during the study period. People may disturb the birds through the battlements, which are short and small in size. 


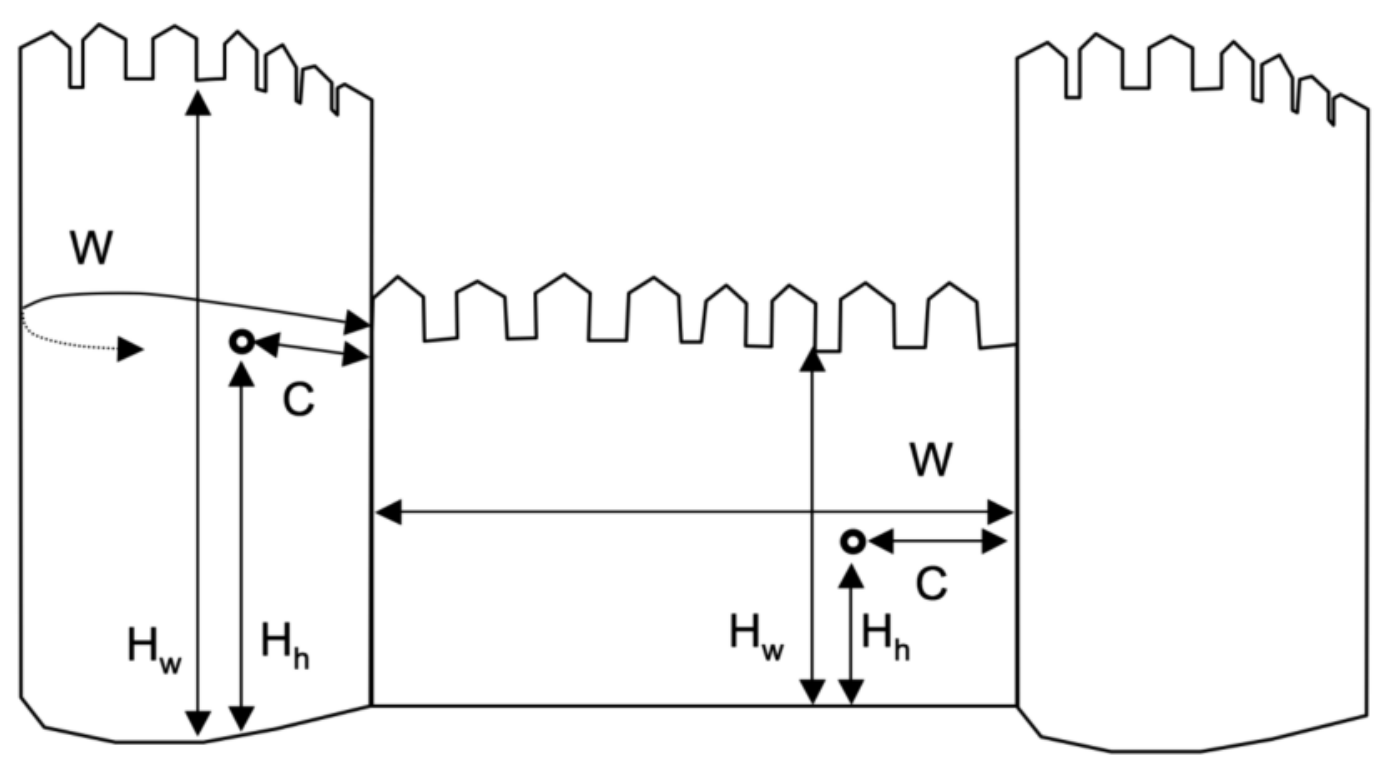

FIG. 2.-Diagram of the measurements taken for cavities in walls and towers: height of hole $\left(\mathrm{H}_{\mathrm{h}}\right)$, distance to the nearest corner $(\mathrm{C})$, wall height $\left(\mathrm{H}_{\mathrm{w}}\right)$ and wall length $(\mathrm{W})$.

[Diagrama de las distancias medidas en cavidades de paredes y torres. Las distancias fueron la altura del agujero $\left(H_{h}\right)$, la distancia a la esquina más cercana $(C)$, la altura de la pared $\left(H_{w}\right)$ y la longitud de la pared $(W)$.

\section{Statistical analyses}

The randomness of the frequency distributions of nests (presence, absence) according to the factors 'building type' (tower, wall) and 'height of cavity' (centred, extreme) was tested with the chi-square test. The statistical effects of the two previous factors on the distances and sizes of the holes were analysed with Generalised Linear Models (GLM) in JMP (SAS Institute, 2009). Continuous data were modelled in GLM with a normal distribution and an identity link function. The descriptive statistics are shown in the text as the mean \pm standard deviation and in the figures as the mean \pm standard error. The means calculated with small sample sizes $(\mathrm{N}<10)$ were compared with the non-parametric Wilcoxon-Mann Whitney $W$ statistic test.
We calculated two types of regression models (stepwise and logistic ordinal) to compute the probability of nesting as a function of entry size, cavity depth, distance from a cavity to the nearest corner, and cavity height above ground. Nesting was coded as an ordinal variable $(0,1)$. Predictors were selected following a mixed forwardbackward stepwise process, with P-values to enter and leave of 0.25 . Selected variables were subjected to logistic analysis to calculate the variable regression coefficients, the Ward statistic and the R-square of the model. Stepwise and logistic regression models were calculated twice: first with all holes, and second with unsuitable holes excluded. The first analysis aimed to identify the physical variables that best predicted the use of any cavity for nesting. The second sample was selected to identify the physi- 
TABLE 1

Mean dimensions $( \pm \mathrm{SD}$ ) for cavities with (Used, $\mathrm{N}=63$ ) and without (Empty, $\mathrm{N}=300$ ) nests. The ranges (minimum-maximum) are included. Statistical results for comparison of means are the Student t-test, degrees of freedom (d.f.), and P-value (P). Measurements of empty cavities are shown in two subgroups: empty cavities with dimensions ranges similar to those with a nest (Suitable, $N=129$ ) and empty cavities with at least one variable outside the observed range of cavities with nest (Unsuitable, $\mathrm{N}=171$ ). Suitable cavities are split in two subgroups according to their height: empty cavities at heights within the range of nests (Central, $\mathrm{N}=72$ ) and empty cavities beyond the height limits of nests (Extreme, $\mathrm{N}=57$ ).

\begin{tabular}{lccccc}
\multicolumn{1}{c}{ Variable } & Used & & Empty & \multicolumn{1}{c}{$\boldsymbol{c}$} \\
\hline Maximum entry distance $(\mathrm{cm})$ & $7.8 \pm 2.1$ & $(4.0-12.0)$ & $6.5 \pm 3.4$ & $(1.0-27.0)$ & 3.0 \\
Minimum entry distance $(\mathrm{cm})$ & $4.8 \pm 1.2$ & $(3.0-7.9)$ & $3.3 \pm 1.7$ & $(0.5-8.0)$ & 6.5 \\
Entry size $(\mathrm{cm})$ & $39.1 \pm 17.0$ & $(12.0-77.0)$ & $24.7 \pm 20.4$ & $(0.7-132.0)$ & 5.2 \\
Hole depth $(\mathrm{cm})$ & $24.3 \pm 6.7$ & $(14.0-50.0)$ & $19.0 \pm 10.8$ & $(1.0-56.0)$ & 3.8 \\
\hline
\end{tabular}

cal variables that best predicted the probability of nesting in cavities with suitable dimensions.

\section{RESULTS}

We found 300 empty cavities and 63 with nests. The empty cavities were shallower than those with nests, and the entry size was smaller in the former than in the latter (table 1). The depth in 64 empty cavities was no greater than $9 \mathrm{~cm}$. The minimum depth in cavities with a nest had been recorded in a previous study (Corrales et al., 2013). In 135 empty cavities the entry was narrower than $3 \mathrm{~cm}$ and in eight empty cavities it was greater than $13 \mathrm{~cm}$. Both distances of $3 \mathrm{~cm}$ and $13 \mathrm{~cm}$ were, respectively, the minimum and maximum entry widths of cavities with nests (Corrales et al., 2013). Overall there were 171 empty cavities with one or more dimen- sions outside the range measured in cavities with nests. We defined these 171 cavities as unsuitable for nesting. We looked for additional differences between the remaining 129 cavities that were empty but apparently suitable for nesting and the 63 cavities with nests. As expected, there were no significant differences in orifice measurements between empty but apparently suitable cavities and cavities with nests (means are shown in table 1).

In walls we found 22 cavities with a nest and 35 suitable but empty cavities. In towers we found 41 cavities with a nest and 94 suitable but empty cavities. Suitable cavities, whether or not they had a nest, were proportionally more frequent in towers $\left(\chi_{1}^{2}=9.7\right.$, $\mathrm{P}=0.002)$ taking into account the length of walls and towers. The cavities were no more frequent in towers than in walls when the surface area explored was taken into account $\left(\chi_{1}^{2}=0.3, P=0.555\right)$. Density of cavities was 
TABLE 1 (cont.)

[Valores medios $\pm S D$ de las cavidades con nidos $(N=63)$ y sin nidos $(N=300)$. Son incluidos los rangos (mínimo-máximo). Los resultados estadísticos para la comparación de las medias son la t de Student, los grados de libertad (d.f.) y el valor de significación $(P)$. Las medidas de las cavidades vacías se muestran en dos subgrupos: cavidades vacías con dimensiones dentro del rango de las cavidades con nido (Adecuadas, $N=129$ ) y cavidades vacías con al menos una variable fuera de los rangos observados en cavidades con nido (Inadecuadas, $N=171$ ). Las cavidades adecuadas son divididas en dos subgrupos según su altura: cavidades vacías con alturas dentro del rango de las que tienen nidos (Central, $N=72$ ) y cavidades vacías más allá de los límites de altura de las que tienen nidos (Extremo, $N=57$ ).]

Empty

\begin{tabular}{|c|c|c|c|c|c|}
\hline \multirow[b]{2}{*}{ d.f. } & \multirow[b]{2}{*}{$\mathbf{P}$} & \multicolumn{2}{|c|}{ Suitable } & \multirow[b]{2}{*}{ Unsuitable } & \multirow[b]{2}{*}{ Variable } \\
\hline & & Central & Extreme & & \\
\hline 361 & 0.003 & $8.0 \pm 1.8$ & $8.0 \pm 1.9$ & $5.3 \pm 3.9$ & Maximum entry distance $(\mathrm{cm})$ \\
\hline 361 & $<0.001$ & $4.8 \pm 1.1$ & $4.9 \pm 1.1$ & $2.2 \pm 1.2$ & Minimum entry distance $(\mathrm{cm})$ \\
\hline 361 & $<0.001$ & $39.0 \pm 14.7$ & $39.1 \pm 14.4$ & $13.8 \pm 17.2$ & Entry size $(\mathrm{cm})$ \\
\hline 361 & $<0.001$ & $25.7 \pm 7.7$ & $23.9 \pm 7.5$ & $14.4 \pm 10.6$ & Hole depth $(\mathrm{cm})$ \\
\hline
\end{tabular}

0.06 holes $/ \mathrm{m}^{2}$. The proportion of holes with a nest did not differ between walls and towers $\left(\chi_{1}^{2}=0.3, \mathrm{P}=0.271\right)$.

Although suitable cavities were present between 1 and $16 \mathrm{~m}$ above the ground, nests were located only in cavities above $3.5 \mathrm{~m}$ and below $12.2 \mathrm{~m}$ (fig. 3). The minimum distance of a nest to the top of the wall was $1.7 \mathrm{~m}$, four times greater than the equivalent distance of a suitable but empty hole $(0.4 \mathrm{~m})$. This was not an exception, but rather a statistical pattern: the distance of the $5 \%$ of nests nearest to the top was $1.8 \pm 0.1 \mathrm{~m}(\mathrm{~N}=3)$, a greater distance than the $1.1 \pm 0.4 \mathrm{~m}$ as calculated with the $5 \%$ nearest suitable but empty cavities $(\mathrm{N}=6$, Wilcoxon Mann Whitney rank test, $\mathrm{W}=6, \mathrm{P}<0.012)$. The same result was observed in cavities at the bottom: the height of the lowest nest was $3.5 \mathrm{~m}$, four times greater than the height of the lowest suitable but empty hole $(0.4 \mathrm{~m})$. Again, this was not an exception but a statis- tical pattern: the mean height of the $5 \%$ of the lowest nests was $3.8 \pm 0.2 \mathrm{~m}(\mathrm{~N}=3)$, greater than the $5 \%$ lowest suitable but empty cavities $(1.0 \pm 0.0 \mathrm{~m}, \mathrm{~N}=6$, Wilcoxon Mann Whitney rank test, $\mathrm{W}=6, \mathrm{P}<0.012)$.

Within the height range of nests (3.5$12.2 \mathrm{~m})$, there were 72 suitable but empty holes ('centred' cavities hereafter, fig. 3). More nests were found in towers than in walls, at heights between 3.5 and $12.2 \mathrm{~m}$ (41 and 22, respectively), but swifts did not show a preference for towers after the number of centred cavities available in each site was taken into account $\left(\chi_{1}^{2}=0.7, \mathrm{P}=0.411\right)$.

Swifts nested in cavities located at $7.5 \pm$ $2.3 \mathrm{~m}$, a mean height close to half the height of the towers and walls $(7.3 \mathrm{~m}$, Student $t$-test, $t=0.8, \mathrm{df}=191, \mathrm{P}=0.399)$. In towers the mean height of nests $(8.0 \pm 2.4 \mathrm{~m}, \mathrm{~N}=41)$ and the mean height of suitable but empty cavities $(7.3 \pm 3.9 \mathrm{~m}, \mathrm{~N}=94$ cavities, centred and extreme combined) did not differ 
$\left(\mathrm{GLM}, \chi_{1}^{2}=1.0, \mathrm{P}=0.309\right)$. The same result was seen in walls: the mean height of nests $(6.6 \pm 1.8 \mathrm{~m}, \mathrm{~N}=22)$ and the mean height of empty holes $(5.5 \pm 2.6 \mathrm{~m}, \mathrm{~N}=35$, centred and extreme combined) did not differ $\left(\mathrm{GLM}, \chi_{1}^{2}=3.6, \mathrm{P}=0.06\right)$. The frequency distribution of the heights of holes suggests that swifts avoided the highest and lowest holes in towers and as well as the lowest holes in walls (fig. 3). The statistical analysis of variance between heights of nests and heights of empty but suitable holes (centred and extreme combined) indeed showed that variances were significantly different in the towers and as well as the walls (Levene test of variances, $F_{1,133}=12.5, \mathrm{P}<0.001$ and $F_{1,55}=10.4, \mathrm{P}=0.002$, towers and walls respectively). After excluding suitable but empty holes at the extreme heights, we found that the variance of the cavity height

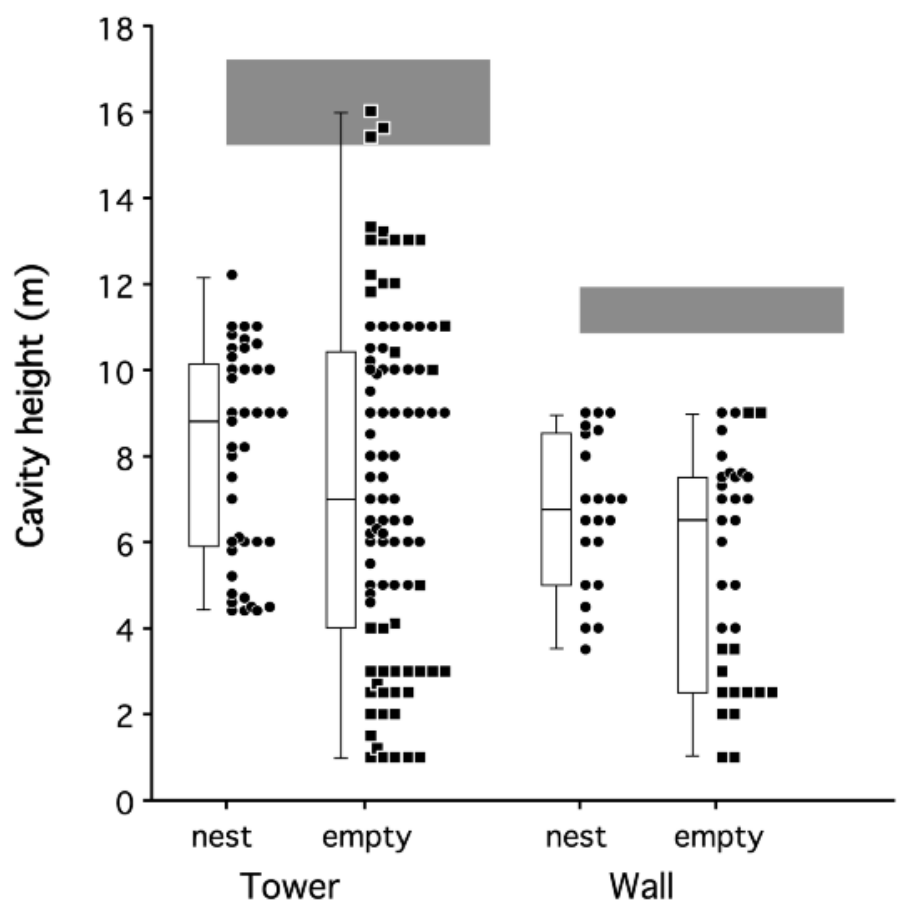

Frequency distribution of suitable cavities (n)

FIG. 3.-Frequency distribution and boxplots of occupied cavities heights and empty but apparently suitable cavity heights in towers and walls. Empty holes at extreme heights are shown with squares. The range of heights (minimum-maximum) of towers and walls are displayed with a grey band. Notice that some extreme cavities (squares) had the same height as centred cavities (circles) because they were located in towers or walls of different heights.

[Distribución de frecuencias y diagramas de cajas de alturas de cavidades ocupadas y cavidades aparentemente adecuadas pero vacías en torres y paredes. Los cuadrados muestran los agujeros vacíos en alturas extremas. Se muestra con una banda gris el rango de alturas (mínimo-máximo) de torres y paredes. Algunas cavidades extremas (cuadrados) tenían la misma altura que las cavidades centradas (círculos) porque fueron localizadas en torres o paredes de altura diferente.] 
in towers did not differ between the holes with nests and the empty but suitable holes (Levene test of variances, $F_{1,90}=2.8, \mathrm{P}=$ $0.100)$. The same result was obtained in the walls (Levene test of variances, $F_{1,41}=1.5$, $\mathrm{P}=0.227)$. We concluded that swifts did not show active selection of cavity height within the central range of heights, because the variances of the used cavities and the suitable cavities were not different. This finding is further supported by comparing the mean heights of the used and the empty suitable cavities. The mean height of centred suitable but empty holes in towers $(8.0 \pm 2.1$ $\mathrm{m}, \mathrm{N}=51$ ) did not significantly differ from the mean height of holes with nests (GLM, $\left.\chi_{1}^{2}=0.0, \mathrm{P}=0.969\right)$. The same result was seen in walls: the mean height of suitable but empty holes in the central subsample (6.9 \pm $1.4 \mathrm{~m}, \mathrm{~N}=21$ ) did not significantly differ from the mean height of holes with nests $\left(\mathrm{GLM}, \chi_{1}^{2}=0.2, \mathrm{P}=0.622\right)$. Note that these comparisons are not as trivial as they seem because the limits of the height in the central suitable but empty holes were set by the height range of nests (minimum and maximum heights), and not by their variance.

Nests were located at $3.5 \pm 2.6 \mathrm{~m}$ from the nearest corner, a shorter distance than that observed in the suitable but empty holes $(4.3 \pm 2.8 \mathrm{~m}$, Student $t$-test: $t=2.1, \mathrm{df}=190$, $\mathrm{P}=0.04)$. The statistical difference increased when compared to the subsample of the extreme suitable but empty holes (fig. 4). The nests in towers were not closer to the corner than the nests in walls (Student $t$-test:

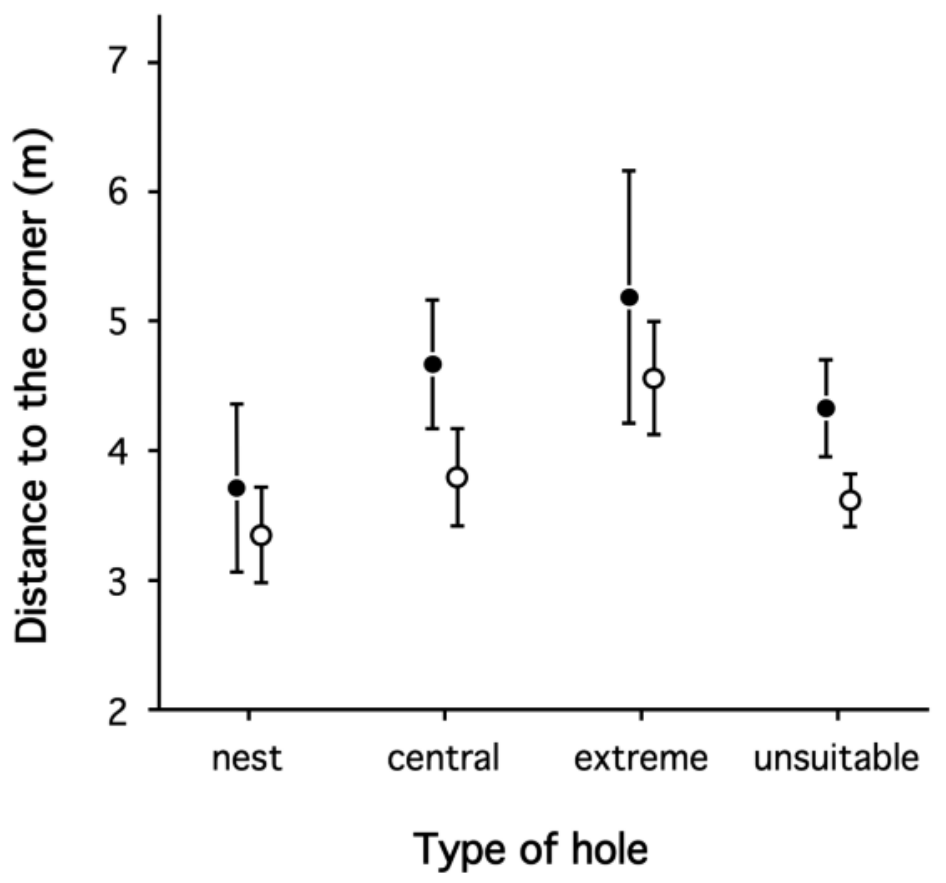

FIG. 4.-Distance to the nearest corner (mean \pm SE) in towers (empty circles) and walls (filled circles) for each cavity type.

[Distancia a la esquina más cercana (media \pm SE) en torres (círculos vacíos) y paredes (círculos llenos) de cada tipo de cavidad.] 
$t=0.5, \mathrm{df}=61, \mathrm{P}=0.30)$. The distance to the nearest corner did not significantly differ between towers and walls in any of the three categories of empty holes (suitable and centred, suitable at extreme heights, and unsuitable). A statistical analysis of both factors combined, the type of hole (used, centred and extreme) and the type of building (tower vs wall), on the distance to the corner did not modify the previous result: although the full model was significant $(\mathrm{N}=192$ holes, GLM, $\left.\chi_{3}^{2}=8.3, P=0.041\right)$, the mean corner distances remained not significantly different between towers and walls (GLM, $\left.\chi_{1}^{2}=2.1, \mathrm{P}=0.151\right)$, as did the interaction between both factors (GLM, $\chi_{2}^{2}=0.3$, $\mathrm{P}=0.876)$. Removing the interaction did not change the result: the building type had no significant effect on the distance to the nearest corner (GLM, $\left.\chi_{1}^{2}=2.1, \mathrm{P}=0.145\right)$. Mean distances to the corner were significantly different according only to the type of hole in the combined model (GLM, $\chi_{2}^{2}=6.8$, $\mathrm{P}=0.033$, fig. 4). We concluded that nests were located closer to the corners than central and extreme holes, with no effect according to the type of building.

The vertical and horizontal positions of cavities significantly predicted the likelihood of nesting in the medieval city of Ávila when unsuitable holes were either included or excluded from the analyses (table 2). Bear in mind that we included the distance to the ground twice (height and height ${ }^{2}$ ) to account for the non-linear relationship with the probability of nesting (fig. 3). When all holes were included in the analysis, the stepwise regression also selected the minimum length

\section{TABLE 2}

Coefficients (B) and statistics of the logistic function to assess the likelihood of swifts nesting in a cavity in the medieval walls of the city of Ávila. Analyses were calculated (a) with all cavities and (b) with unsuitable cavities excluded.

[Coeficientes (B) y estadísticos de la función logística para evaluar la probabilidad de anidar de los vencejos en una cavidad en las paredes medievales de la ciudad de Ávila. Los análisis fueron calculados (a) con todas las cavidades y (b) con cavidades inadecuadas excluidas.]

\begin{tabular}{lrrrr}
\hline \multicolumn{1}{c}{ Variable } & B & SE $(\mathbf{B})$ & Wald & P \\
\hline (a) All cavities $(\mathbf{N}=\mathbf{3 6 3})$ & & & & \\
Minimum entry distance & 0.543 & 0.105 & 26.7 & $<0.001$ \\
Height & 1.406 & 0.326 & 18.6 & 0.022 \\
Height squared & -0.092 & 0.022 & 17.6 & $<0.001$ \\
Distance to the corner & -0.142 & 0.062 & 5.3 & 0.022 \\
Depth & 0.029 & 0.017 & 2.8 & 0.093 \\
\hline (b) Suitable and used cavities $(\mathbf{N}=\mathbf{1 9 2})$ & & & & \\
Height & 1.314 & 0.337 & 15.2 & $<0.001$ \\
Height squared & -0.083 & 0.022 & 13.8 & $<0.001$ \\
Distance to the corner & -0.129 & 0.064 & 4.1 & 0.043 \\
\hline
\end{tabular}


of the orifice entry and the cavity depth as predictors, in addition to the cavity distances to the corner and to the ground. The logistic function explained $24.3 \%$ of the probability of nesting $\left(\mathrm{N}=363, \chi_{5}^{2}=81.2, \mathrm{P}<0.001\right)$ when all holes were included, and $12.1 \%$ when unsuitable holes were excluded $(\mathrm{N}=$ $\left.192, \chi_{3}^{2}=29.5, \mathrm{P}<0.001\right)$.

Scats from mice were found in ten out of 129 suitable but empty cavities, and in one out of 63 cavities with nests. Thus, mouse scats were marginally more frequent in empty than in used cavities $\left(\mathrm{N}=192, \chi_{1}^{2}=\right.$ $3.7, \mathrm{P}=0.056)$. The percentage of suitable but empty cavities with mouse scats was $6.9 \%$ in centred cavities and $8.8 \%$ in extreme cavities. Thus, mouse scats were not more frequent in cavities at extreme heights $(\mathrm{N}=$ $\left.129, \chi_{1}^{2}=0.1, \mathrm{P}=0.701\right)$. The mean height of holes with mouse scats was $8.4 \pm 3.7 \mathrm{~m}$ $(\mathrm{N}=11)$, no higher than the holes without mouse scats $\left(7.0 \pm 3.3 \mathrm{~m}\right.$, ANOVA $\mathrm{F}_{1,190}=$ $2.0, \mathrm{P}=0.160)$. Cavities with mouse scats did not differ in size from cavities with swift nests ( $t$ tests of maximum and minimum entry distances, entry size and hole depth, df $=53$, all $\mathrm{P}>0.128$ )

\section{DISCUSSION}

Nesting swifts in the medieval city walls of Ávila avoided cavities situated at extreme heights, those too shallow to support a nest and those with entry sizes that were too narrow or too wide. These are common observations in cavity-nesting species, which usually select an entry width that can limit the size of potential predators entering the cavity but with a diameter large enough for the resident bird to enter (Wesolowski, 2002). Both limits were observed in unsuitable cavities: entry size was either smaller or larger than that of cavities with a nest.

Other bird species compete to some extent with swifts, breeding in the same holes. Com- mon starlings Sturnus vulgaris may displace swifts in territorial disputes for nestboxes (Lack, 1956b). In the study area, there is a large population of spotless starlings $S$. unicolor (Santamaría et al., 2009) but they were not observed breeding in the medieval walls. We did not observe any aggressive interaction between swifts and starlings. House sparrows Passer domesticus were not found, perhaps because swifts easily displace them (Lack, $1956 \mathrm{~b})$, especially when the colony size is large (Genton, 2009). A few nesting sparrows were observed elsewhere in the city walls ( $<5 \%$ of holes, Corrales unpublished), in the medieval towers where the curve of the wall was greatest, and also in smaller holes than those occupied by swifts. The small percentage of holes with sparrows can be explained by displacement by swifts, and also because the typical cavity size is smaller in sparrows: $3 \times 9 \mathrm{~cm}$ and $2 \times 9 \mathrm{~cm}$ inner surfaces, for the house sparrow Passer domesticus and tree sparrow P. montanus, respectively (Cordero, 1986). No bats were found in holes selected by swifts, nor in any unsuitable holes. Although unsuitable holes were too small for swifts, they were too large overall for bats (for example: min. $1.8 \mathrm{~cm}$ in Pipistrellus and $2.5 \mathrm{~cm}$ in Serotinus (Huitema, 2010).

Swift nest size $(12 \times 9 \mathrm{~cm}$; Corrales et al., 2013) requires cavities at least $9 \mathrm{~cm}$ deep to hold the nest and some additional distance to allow arrivals and departures of adults. The minimum depth found in this study was 14 $\mathrm{cm}$. This would indicate that adults avoided holes with sufficient depth to hold the nest but insufficient distance to land and take-off between the nest and the cavity entry. Nest sizes in Ávila did not differ when compared to nests in other parts of Europe (Corrales et al., 2013), perhaps because the body sizes of swifts across Europe were not meaningfully different either (Lack and Lack, 1951). However, nests were located deeper in the nesting cavity at other European sites. For 
instance, in the Czech Republic they were at 20-50 cm (Třeboň) and 20-70 cm (Hrotovice) from the cavity entry (Pellantová, 1975). In Germany the depths ranged between 24 and $29 \mathrm{~cm}$ (Guenther and Hellmann, 2002). Temperatures at those sites are lower than in Ávila, and rain is also heavier during the breeding season, hence it seems likely that swifts positioned the nests deeper in the holes to avoid harsher weather conditions than those in Ávila. Cavity orientation should determine to some extent cavity selection because weather is an obvious consideration to explain why swifts nested near corners. Wall orientation effects on cavity selection in Ávila should be explored further.

Swifts nested in about half $(48 \%)$ of the suitable holes located within the central strip of the medieval walls. That percentage of use was greater than in other swift species (A. pallidus and A. melba; Brichetti et al., 1988). The high percentage of use in suitable centred holes and the large population of swifts in Ávila (between 6,222 and 8,091 birds $\cdot \mathrm{km}^{-2}$ in the historic district between the years 2006-2009; L. Corrales, unpublished), suggests that nest-site competition in the medieval city walls of Ávila is strong.

We did not measure breeding success and therefore we cannot relate nest location to breeding success. Several studies of other (Gil-Delgado and Barba, 1987; Nilsson, 1984; Osborne and Osborne, 1980; Tenaza, 1971; Best, 1978) show that higher nests suffer lower predation risks. Birds breeding early in the season often achieve higher breeding success. Hence, one approach in future studies is to explore the link between fitness and nest selection by sampling throughout the breeding season to determine whether early and late breeders are similarly distributed in the walls. On the other hand, studies of cliff-nesting birds report a significant effect of the distance from the top of the cliff on hatching success (Harris et al., 1997). Perhaps predation risk at the nest is not a main concern in swift species, as has been shown in the american black swift Cypseloides níger (Hirshman et al., 2007), but we cannot disregard predation risk as the main explanation for the height of cavity selection in the Ávila walls as swift nests were not found in high and low holes suitable for breeding. A plausible explanation is that swifts avoid the highest and lowest holes due to the presence of mice, a potential predator of eggs in other species of Apus (Penloup and Martin, 1995; Penloup et al., 1997). However, we did not find more mice in empty cavities at extreme heights, and therefore we cannot conclude that swifts avoided extreme heights to reduce predation risk from mice. Simple experiments can be done to test predation pressure in relation to distance from the wall bottom or top by measuring the survival of artificial eggs placed at different heights. In the same vein, it would be interesting to examine the distribution of nests in towers or walls with restricted human access. The upperside of the walls was open to pedestrians and tourists: 22,762 tourists accessed these areas in April and 15,431 in May, 2011 and an average of 21,526 for April and 16,725 for May in the last decade (Troitiño et al., 2012). This activity could cause disturbance to breeding swifts. Disturbance from pedestrians may be detrimental to breeding sparrows (Sacarrao and Soares, 1975; Nilsson, 1984), and is also likely to be detrimental to breeding swifts. On the other hand, we did not find any nest in holes below $3.5 \mathrm{~m}$, the same height as in other studies (Bernis, 1988b; Lack, 1956b).

Acknowledgements.- We thank the City Council of Ávila for allowing us to access the nests in the medieval walls surrounding the city. The company Construcción y Desarrollo de Servicios S.A. (VOLCONSA) restored the towers and walls included in this study, and helped us to locate the holes before they performed the maintenance work on the medieval city walls. We also 
thank Pablo Corrales for assisting in fieldwork. Ernest Garcia and Sarah Young kindly reviewed the English translation.

\section{BIBLIOGRAPHY}

Alonso, J. A., Muñoz-Pulido, R., Bautista, L. M. and Alonso, J. C. 1991. Nest-site selection and nesting success in the azure-winged magpie in central Spain. Bird Study, 38: 45-51.

Beaud, M. 2010. Common swift Apus apus, nesting on the molasse cliffs of the river Sarine (Fribourg, Switzerland). A recapitulation of breeding at natural sites throughout Switzerland. Nos Oiseaux, 57: 265-276.

BERNIS, F. 1988a. Los Vencejos. Su biología, su presencia en las mesetas españolas como aves urbanas. Universidad Complutense de Madrid. Madrid.

Bernis, F. 1988b. Aves de los medios urbano y agrícola en las mesetas españolas. Monografías $n^{\circ} 2$. SEO/BirdLife. Madrid.

Beschow, R. 2003. Tree-breeding swifts Apus apus in the city of Spremberg. Result of a survey of swift population 2003. Ornithologische Jahresberichte des Museum Heineanum, 21: 47-55.

Best, L. B. 1978. Field sparrow reproductive success and nesting ecology. Auk, 95: 9-22.

Brichetti, P., Foschi, U. F. and Gellini, S. 1988. Distribuzione e consistenza delle colonie di Apodidae del Promontorio del Gargano (Puglia). Rivista Italiana di Ornitologia, 58: 53-58.

Cameliti, G. and Boano, G. 2002. Nesting of the swift Apus apus in tree cavities in Turin. Picus, 28: 105-107.

Corrales, L., Santamaría, T., Mas, P. and CamPOS, F. 2013. Morfología y composición de los nidos de vencejo común (Apus apus) en Ávila (España). Cuadernos Abulenses, 41: 47-69.

Cordero, P. J. 1986. Aspectos de la ecoetología de la nidificación en el gorrión molinero (Passer m. montanus, (L.)) y el gorrión común (Passer d. domesticus, (L.)) en Cataluña. Tesis Doctoral, Universidad de Barcelona.

CORTES, J. 2005. Nesting of common swifts Apus apus in palm trees. Gibraltar Bird Report, 4: 54-56.
Ferrero, J. J., Negro J. J., Román, J. A., CAbrero, M., Gutiérrez, A. and Pizarro, V. M. 1983. Cría de vencejo común en árboles. Ardeola, 30: 121.

FISHER, R. J. and WIEBE, K. L. 2006. Nest site attributes and temporal patterns of northern flicker nest loss: effects of predation and competition. Oecologia, 147: 744-753.

Forero, M. G., Tella, J. L., DonáZar, J. A. and HirAldo, F. 1996. Can interspecific competition and nest site availability explain the decrease of lesser kestrel Falco naumanni populations? Biological Conservation, 78: 289-293.

Franco, A. M. A., Marques, J. T. and SutherLAND, W. J. 2005. Is nest-site availability limiting lesser kestrel populations? A multiple scale approach. Ibis, 147: 657-666.

FroEHLICH, C. 2006. Swifts (Apus apus) visiting tree holes in a natural forest reserve in the south western Palatinate (Rhineland-Palatinate). Fauna und Flora in Rheinland-Pfalz, 10: 1401-1402.

GÁMEZ, I. 1989. Nidificación en árboles. Ardeola, 36: 256.

García, J. A. and Álvarez, C. 1996. Cría probable en robles. Ardeola, 43: 253.

Genton, B. 2009. Inter-specific relationships between the common swift Apus apus and the house sparrow Passer domesticus, some original ideas in favour of the common swift. Nos Oiseaux, 56: 67-86.

Gil-Delgado, J. A. and Barba, E. 1987. Aves nidificantes en huecos de los naranjos. Mediterránea Serie Biología, 9: 29-40.

Guenther, E. and Hellmann, M. 2002. Strong decrease of population of tree-breeding swift Apus apus in the northeastern Harz Mountains (Sachsen-Anhalt) - was it the racoon Procyon lotor?. Ornithologische Jahresberichte des Museum Heineanum, 20: 81-98.

Guenther, E. and Hellmann, M. 2009. The super hole- common swifts Apus apus breeding in a treehole in the course of 25 years. Ornithologische Jahresberichte des Museum Heineanum, 27: 79-83.

Harris, M. P., WANless, S., Barton, T. R. and Elston, D. A. 1997. Nest site characteristics, duration of use and breeding success in the guillemot Uria aalge. Ibis, 139: 468-476. 
Herrera, C. M. and Ramírez, A. 1975. El vencejo común nidificando en árboles. Ardeola, 22: 146.

Hirshman, S. E., Gunn, C. and Levad, R. G. 2007. Breeding phenology and success of black swifts in Box Canyon, Ouray, Colorado. Wilson Journal of Ornithology, 119: 678-685.

Huber, H. 1990. Breeding site of the swift (Apus apus) in rocks of shell limestone. Ornithologische Jahrbuch Baden-Württemberg, 6: 91-94.

Huitema, H. 2010. Verborgen dierenleven onder dak. Dakenraad, 95: 58-61.

Kharkova, O. Y. and Boehme, I. R. 2005. Patterns of location of bird nests in an oak forest in the Nature Reserve "Les na Vorskle" (Russia). Berkut, 14: 201-213.

Holmgren, J. 1993. Young common swifts roosting in foliage of trees. British Birds, 86: 358-369.

LACK, D. 1956a. A review of the genera and nesting habits of swifts. Auk, 73: 1-32.

LACK, D. 1956b. Swifts in a Tower. Methuen. London.

LACK, D. and LACK, E. 1951. The breeding biology of the swift Apus apus. Ibis, 93: 501-546.

Newton, I. 1998. Population Limitation in Birds. San Diego Academic Press.

Nilsson, S. G. 1984. The evolution of nest-site selection among hole-nesting birds: The importance of nest predation and competition. Ornis Scandinavica, 15: 167-175.

Osborne, P. and OsBorne, L. 1980. The contribution on nest site characteristics to breeding success among Black birds (Turdus merula). Ibis, 122: 512-517.

Pellantová, J. 1975. The course of breeding of the swift (Apus apus Linn.) Zoologické Listy, 24: 249-262.

Penloup, A. and Martin, J. L. 1995. Conséquences de la prédation des nids par le rat noir sur la distribution du martinet pâle (Apus pallidus) dans la Bouches de Bonifacio. Parc naturel régional de Corse, 56: 49-69.
Penloup, A., Martin, J. L., Gory, G., Brunstein, D. and Bretagnolle, V. 1997. Distribution and breeding success of pallid swifts, Apus pallidus, on Mediterranean islands: nest predation by the roof rat, Rattus rattus, and nest site quality. Oikos, 80: 78-88.

Roger, T. and Fossé, A. 2001. Nidifications arboricole et rupertre du martinet noir Apus apus en Maine-et-Loire. Crex, 6: 21-29.

Santamaría, T., Corrales, L., Campos, F. and Alonso, C. 2009. Los Estorninos en la Ciudad de Ávila. Situación Actual y Problemática. Universidad Católica de Ávila. Ávila.

Sacarrao, G. F. and Soares, A. A. 1975. Algumas observações sobre a biología de Passer hispaniolensis (Temm.) em Portugal. Estudos sobre a Fauna Portuguesa, 8: 1-20.

TenAzA, R. 1971. Behaviour and nesting success relative to nest location in Adelie Penguins (Pygoscelis adeliae). Condor, 73: 81-92.

Troitiño, M. Á., García, M., Calle, M., Mínguez, M. C., Troitiño, L. and Velasco, I. 2012. Boletín Informativo del Observatorio Turístico de la Ciudad de Ávila, n 28. Ayuntamiento de Ávila. Ávila.

Van Balen, J. H., Booy, C. J. H., van Franeker, J. A. and OsIECK, E. R. 1982. Studies on holenesting birds in natural nest sites. Ardea, 70: $1-24$.

Vielliard, J. 1978. Le Djebel Babor et sa sittelle Sitta ledanti Vielliard. Alauda, 46: 1-42.

WesOlOWSKI, T. 2002. Anti-predator adaptations in nesting marsh tits Parus palustris: the role of nest-site security. Ibis, 144: 593-601.

Received: 22 April 2013 Accepted: 4 June 2013

Editor: Jesús M. Avilés 